\title{
EVALUASI MANAJEMEN KEAMANAN INFORMASI MENGGUNAKAN INDEKS KEAMANAN INFORMASI (KAMI) PADA JARINGAN (STUDI KASUS : UIN SUNAN KALIJAGA YOGYAKARTA)
}

\author{
Rizki Dewantara*1, Bambang Sugiantoro \\ ${ }^{1,2}$ Universitas Islam Negeri Sunan Kalijaga, Yogyakarta \\ Email: 1dewantararizki@gmail.com, bambang.sugiantoro@uin-suka.ac.id \\ *Penulis Korespondensi
}

(Naskah masuk: 20 Januari 2020, diterima untuk diterbitkan: 15 November 2021)

\begin{abstract}
Abstrak
Serangan pada jaringan saat ini sangat sering terjadi, dengan semakin banyaknya cara untuk melakukan pengaksesan terhadap data dan semakin berkembangnya teknologi yang digunakan tentunya akan menyebabkan meningkatnya ancaman keamanan suatu jaringan. Evaluasi manajemen keamanan informasi menggunakan indeks keamanan informasi (KAMI) yang dilakukan pada jaringan di UIN Sunan Kalijaga Yogyakarta didapatkan hasil indeks 407, yang dianggap masih belum optimal. Hal ini yang mendasari perlunya implementasi Open Source SIEM (OSSIM) ke dalam indeks KAMI. Penelitian ini dilakukan untuk mengoptimalkan proses keamanan informasi agar dapat bekerja sesuai dengan standar indeks KAMI. Metode penelitian yang digunakan meliputi studi literatur, melakukan Pre-Assesment Indeks KAMI, mengimplementasi infrastruktur OSSIM, monitoring indeks keamanan informasi menggunakan teknologi OSSIM, dan melakukan Post-Assesment Indeks KAMI, tahapan akhir ini menganalisis hasil monitoring untuk dibuat perbandingan bagaimana kondisi jaringan sebelum dan sesudah diimplementasikan OSSIM pada jaringan. Skor nilai perbandingan dari hasil penelitian terkait Indeks KAMI menunjukkan peningkatan skor penilaian sebesar 25 , setelah diterapkan penggunaan OSSIM dari sebelumnya tanpa penerapan OSSIM sebesar nilai 407 menjadi 432. Peningkatan indeks KAMI membantu menaikan nilai pada aspek tata kelola, pengelolaan asset dan teknologi, namun tingkat kelayakan keamanan informasi masih di level I+ sampai dengan II+ sehingga keamanan informasi pada jaringan tidak layak dan butuh perbaikan.
\end{abstract}

Kata kunci: Indeks KAMI, Keamanan Informasi, Open Source SIEM (OSSIM)

\section{EVALUATION OF INFORMATION SECURITY MANAGEMENT USING INFORMATION SECURITY INDEX (KAMI) ON THE NETWORKS (CASE STUDY: UIN SUNAN KALIJAGA YOGYAKARTA)}

\begin{abstract}
Attacks on networks today are very common, with more and more ways to access data and the development of technology used, they will certainly cause an increase in network security threats. Evaluation of information security management using the information security index (KAMI) conducted on the network at UIN Sunan Kalijaga Yogyakarta obtained an index result of 407, which is considered still not optimal. This underlies the need to implement Open Source SIEM (OSSIM) into the KAMI index. This research was conducted to optimize the information security process so that it can work according to the KAMI index standards. The research methods used include literature study, conducting KAMI Index Pre-Assessment, implementing OSSIM infrastructure, monitoring information security index using OSSIM technology and conducting KAMI Index Post-Assessment, this final stage analyzes the results of monitoring to make comparisons of network conditions before and after implementation of OSSIM on the network. Comparative scores from the results of research related to the KAMI Index show an increase in the score of 25, after applying OSSIM from before without applying OSSIM, the value of 407 becomes 432. The increase in the KAMI index helps raise the value of governance aspects, asset management and technology, but the level of information security eligibility is still at the level of I+ to II+ so the information security on the network is not feasible and needs improvement.
\end{abstract}

Keywords: KAMI Index, Information Security, Open Source SIEM (OSSIM) 


\section{PENDAHULUAN}

Sistem deteksi penyusupan telah berkembang seiring dengan berkembangnya tantangan dan permasalahan yang perlu diakomodasi oleh sistem tersebut (Sugiantoro, 2017). Kebutuhan instansi pemerintahan untuk menerapkan Standar Managemen Keamanan Informasi sesuai dengan Sistem Manajemen Keamanan Informasi (SMKI) dan monitoring terhadap jaringan menjadi pilihan yang mutlak agar security officer dapat dengan jelas melihat apa yang terjadi dengan jaringannya. (MENKOMINFO, 2019).

Open Source Security Information Management (OSSIM) adalah sebuah Platform Security Information Management yang berbasiskan open source dan merupakan kumpulan lebih dari 15 open source security program yang semuanya terkandung di dalam sistem ini untuk menghasilkan kontrol manajemen keamanan pada sebuah jaringan (Hadiansyah chandra and Iskandar, 2017). Sedangkan Indeks Keamanan Informasi (KAMI) merupakan suatu alat untuk mengevaluasi tingkat kematangan, tingkat kelengkapan penerapan SNI ISO/IEC 27001:200 serta peta area tata kelola keamanan sistem informasi di suatu lembaga pemerintahan. Bentuk evaluasi yang diterapkan dalam indeks KAMI dirancang untuk dapat digunakan oleh instansi pemerintah dari berbagai tingkatan, ukuran, maupun tingkat kepentingan penggunaan IT dalam mendukung terlaksananya tugas pokok dan fungsi yang ada. Indeks penilaian keamanan informasi untuk mengukur kematangan manajeman keamanan layanan TI yaitu semakin tinggi ketergantungan terhadap TIK maka harus semakin banyak bentuk pengamanan yang di terapkan sampai tahap tertinggi (Lenawati, Winarno and Amborowati, 2017). Berdasarkan pada penilaian resiko bahwa resiko bernilai ekstrim adalah kehilangan integritas informasi, kegagalan perangkat dan layanan, gangguan komunikasi, dan kegagalan sistem/alat sehingga dibuatkan kontrol akses yang berkaitan dengan asset tersebut. Untuk menangani masalah ini, MENKOMINFO memperkenalkan Indeks KAMI sebagai alat untuk menilai tingkat kematangan institusi untuk memenuhi informasi nasional standar manajemen keamanan. Sebelum standar keamanan informasi diterapkan, perlu dilakukan evaluasi system keamanan informasi di jaringan UIN Sunan Kalijaga Yogyakarta untuk mendapatkan gambaran kondisi kesiapan dan kematangan manajemen keamanan informasi tersebut. Dalam pelaksanaan pengukuran tingkat kematangan manajemen keamanan informasi pada jaringan UIN Sunan Kalijaga Yogyakarta mengunakan model yang di siapkan oleh Kominfo RI tahun 2019, yaitu indeks KAMI. Indeks KAMI dibuat dengan acuan ISO 27001:2018 yang berisi tentang keamanan informasi. ISO 27001 adalah suatu bentuk kerangka kerja standar internasional yang berisi tentang standar-standar dalam area keamanan informasi, lingkup penggunaan teknologi dan pengelolaan asset yang membantu organisasi memastikan bahwa keamanan informasi sudah berjalan dengan efektif (ISO/IEC, 2018). Dibutuhkan upaya-upaya besar untuk memperbaiki keamanan informasi di lembaga pemerintahan untuk menerapkan kontrol dasar risiko dan juga dari strategi keamanan informasi. Data yang digunakan dalam evaluasi ini nantinya akan memberikan gambaran indeks kesiapan keamanan informasi dari aspek kelengkapan maupun kematangan, kerangka kerja, keamanan informasi yang diterapkan yang dapat digunakan sebagai pembanding dalam rangka menyusun langkah perbaikan dan penetapan prioritasnya.

Beberapa penelitian pernah dilakukan terkait evaluasi manajemen keamanan informasi menggunakan indeks keamanan informasi diantaranya Angga Juansyah, Bagus Pratama (2018) pernah melakukan penelitian tentang implementasi OSSIM pada keamanan jaringan komputer di PT. Satria Antaran Prima Palembang dan mendeteksi aktifitas pingflood dan aktifitas pengaksesan router yang dilakukan oleh host dalam jaringan Perusahaan ini. OSSIM yang diimplementasi hanya mampu mendeteksi serangan atau sebagai IDS. (Angga Juansyah, Bagus Pratama, 2018). Selanjutnya penelitian yang dilakukan oleh Putra dan Tjahjadi (2018) membahas tentang Indeks KAMI yang dilakukan dengan melakukan evaluasi keamanan informasi pada perguruan tinggi, untuk mendapatkan sertifikasi ISO/IEC 27001:2009 level keamanan informasi adalah minimal III (Putra and Tjahjadi, 2018). Penelitian selanjutnya dilakukan oleh (Pratama, dkk (2018) yang membahas evaluasi tata kelola sistem keamanan teknologi informasi menggunakan indeks KAMI dan ISO 27001 bahwa tingkat kematangan dan keamanan informasi KOMINFO masih tergolong rendah karena KOMINFO masih dalam perencanaan atau belum mengaplikasikan syarat - syarat keamanan informasi (Pratama, Suprapto and Perdanakusuma, 2018). Kemudian penelitian tentang Evaluasi Manajemen Keamanan Informasi Menggunakan Indeks KAMI berdasarkan ISO/IEC 27001:2013 pada Direktorat Pengembangan Teknologi dan Sistem Informasi (DPTSI) ITS Surabaya yang dilakukan oleh (Basyarahil, dkk (2017), pada penelitian tersebut mengungkapkan hasil diantaranya belum dapat dikatakan matang dan sesuai dengan standar ISO 27001:2013 karena belum mencapai level III+ dimana penerapan keamanan informasi telah terdefinisi dan konsisten (Basyarahil, Astuti and Hidayanto, 2017). Kemudian penelitian tentang Pengukuran Keamanan Informasi PDAM Titra Medal Menggunakan Indeks KAMI Untuk Analisis Tingkat Kematangan Keamanan Informasi yang dilakukan oleh (Sutara, (2018), pada penelitian ini pihak instansi telah menyadari betul bahwa peran teknologi atau TIK sudah sangat jelas memberikan 
kemudahan bagi para staff untuk membantu menjalankan proses bisnis. Perubahan pada keamanan informasi pada intansi dilakukan dengan wawancara dengan kuesioner pada analis jaringan pada suatu intansi agar diketahui celah keamanan informasi (Sutara, 2018). Kemudian penelitian oleh (Akhirina, dkk (2016) mengenai Evaluasi Keamanan Teknologi Informasi Pada PT Indotama Partner Logistics menggunakan Indeks KAMI yang berada di level I+ sampai dengan II+, Hasil dari evaluasi di PT Indotama Partners Logistics terhadap TIK masih belum dilaksanakan secara menyeluruh dan konsisten, akan tetapi masih ditahap penerapan sebagian dan dalam perencanaan (Akhirina, Arif and and Rahmatika, 2016). Kemudian penelitian tentang Indeks Penilaian Keamanan Informasi Untuk Mengukur Kematangan Manajeman Keamanan Layanan TI (Studi Kasus :BPMP Kabupaten Gresik) yang dilakukan oleh (Hidayat, dkk (2018), dengan hasil yaitu semakin tinggi ketergantungan terhadap TIK atau semakin penting peran TIK maka harus semakin banyak bentuk pengamanan yang di perlukan dan harus di terapkan sampai tahap tertinggi (Hidayat, Suyanto and Sunyoto, 2018).

Berdasarkan penelitian-penelitian sebelumnya, peneliti melakukan penggalian terkait konsep dan mengimplementasikan penggunaan OSSIM untuk evaluasi manajemen terhadap peningkatan keamanan informasi di UIN Sunan Kalijaga Yogyakarta dengan menciptakan sistem pendeteksi atau sensor terhadap area jaringan menggunakan aplikasi berbasis open source, yaitu alientvault OSSIM sehingga memberikan laporan kepada administrator sistem mengenai upaya penyerangan terhadap sistem, melalui catatan atau log yang dihasilkan oleh aplikasi sebagai bukti digital yang mencatat segala upaya penyerangan atau penetrasi ke dalam suatu area server. Tujuan dari penelitian ini yaitu memantau dan mengetahui lebih detail permasalahan yang ada pada jaringan UIN Sunan Kalijaga Yogyakarta sehingga dapat diketahui pola solusi untuk mengatasinya kemudian memaksimalkan infrastruktur jaringan komputer yang ada dengan lebih efektif dan efisien sesuai fungsinya sebagai institusi pendidikan, hasilnya dapat digunakan sebagai bahan pertimbangan dalam rangka menyusun langkahlangkah perbaikan manajemen keamanan sistem informasi pada Sistem Informasi UIN Sunan Kalijaga Yogyakarta. Tingkat kelayakan yang rata-rata menduduki level I+ dan II+ tanpa penerapan OSSIM sebesar nilai 407 melalui kuesioner pre-assesment indeks KAMI kepada responden menunjukkan kesiapan sertifikasi masih dikatakan belum layak sertifikasi keamanan informasi, karena untuk mencapai batas minimum kesiapan sertifikasi keamanan informasi adalah tingkat III sehingga diterapkan Open Source SIEM (OSSIM) untuk diimplementasikan didalam Infrastruktur Jaringan UIN Sunan Kalijaga Yogyakarta sehingga dapat meningkatkan indeks KAMI.

\section{METODE PENELITIAN}

Tahapan yang akan dilakukan dalam penelitian terkait evaluasi KAMI (Keamanan Informasi) melalui Manajemen OSSIM (Open Souce SIEM) di UIN Sunan Kalijaga Yogyakarta dapat dilihat pada Gambar 1.

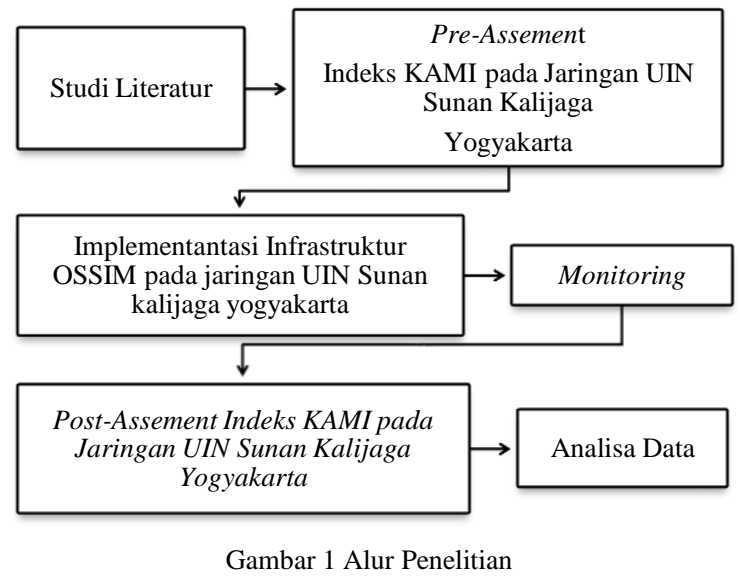

\subsection{Studi Literatur}

Tahapan pertama dalam penelitian ini adalah studi literatur untuk mencari referensi dan landasan teori yang digunakan sebagai dasar dalam melakukan penelitian. Studi literatur dilakukan dengan melakukan review terhadap jurnal sejenis, membaca berbagai sumber pustaka yang terkait sebagai justifikasi awal untuk melihat apakah ada perbedaan jika ada OSSIM dan tanpa pemasangan OSSIM.

\subsection{Pre-Assesment Indeks KAMI Jaringan UIN Sunan Kalijaga Yogyakarta}

Sebelum melakukan proses simulasi untuk implementasi serangan, dan melihat hasil network forensic yang dilakukan, dilakukan paparan mengenai hasil simulasi serangan dan network forensic kemudian dilanjutkan pengisian kuesioner pre-assesment indeks KAMI kepada responden yang dalam hal ini adalah Kepala Divisi Teknologi Informasi dan pangkalan data UIN Sunan Kalijaga Yogyakarta. Hasil kuesioner kemudian dihitung sesuai format aplikasi dari Direktorat Keamanan Informasi Kementerian Komunikasi dan Informatika Indonesia.

\subsection{Implementasi Infrastruktur OSSIM jaringan UIN Sunan Kalijaga Yogyakarta}

Pada tahapan ini infrasruktur OSSIM diimplementasikan dengan infrastruktur berupa satu buah server dan agent yang akan ditempatkan dibeberapa titik pada jaringan UIN Sunan Kalijaga Yogyakarta dengan ruang lingkup jaringan yang akan dipantau dibatasi pada jaringan komputer yang berada di UIN Sunan Kalijaga Yogyakarta. 


\subsection{Monitoring}

Tahapan ini dilakukan untuk memantau jaringan untuk mendeteksi usaha penyusupan dengan Intrusion Detection System, melakukan proses filtering, maupun mendeteksi Instalation pada bandwith yang tidak wajar pada suatu jaringan sebagai akibat dari serangan pada keamanan jaringan, baik bersifat internal maupun eksternal.

\subsection{Post-Assesment Indeks KAMI Jaringan UIN Sunan Kalijaga Yogyakarta}

Setelah dilakukan kegiatan pemaparan hasil monitoring, dilakukan kembali pengukuran mengenai indeks KAMI terhadap responden yang dalam hal ini adalah Kepala Divisi Teknologi Informasi dan pangkalan data UIN Sunan Kalijaga Yogyakarta, dengan memberikan post-assesment Indeks Keamanan Informasi (KAMI) untuk mengukur nilai indeks keamanan informasi tersebut setelah dilakukan monitoring dengan OSSIM. Hasil kuesioner kemudian dihitung sesuai format aplikasi dari Direktorat Keamanan Informasi Kementerian Komunikasi dan Informatika Indonesia. Kemudian hasil tersebut akan dibandingkan dengan hasil dari pre-assesment yang dilakukan sebelumnya. Apakah ada perbedaan atau tidak, perbedaan tersebut berupa penurunan atau peningkatan dalam indeks KAMI terhadap jaringan sistem di UIN Sunan Kalijaga Yogyakarta.

\subsection{Analisis Data}

Tahapan akhir ini menganalisis hasil monitoring untuk dibuat perbandingan bagaimana kondisi jaringan sebelum dan sesudah diimplementasikan Open Souce SIEM( OSSIM) pada jaringan UIN Sunan Kalijaga Yogyakarta. Hasil dari analisis ini dibuat menjadi kesimpulan untuk menjadi bahan masukan dalam manajemen keamanan jaringan di masa depan.

\section{HASIL DAN PEMBAHASAN}

\subsection{Arsitekstur OSSIM}

Arsitekstur dari OSSIM diantaranya sebagai berikut:

1) Sensor, adalah memantau kegiatan-kegiatan suatu sistem jaringan. Segala kejadian pada suatu jaringan atau peristiwa peristiwa yang dapat diterima oleh server OSSIM ini menggunakan sensor, pada hal ini sensor mampu disebut sebagai pendeteksi.

2) Manajement server, adalah pusat dari segala informasi yang diterima dari sensor-sensor OSSIM. Adapun fungsi dari Manajemen Server ini adalah:

a. Server utama yang berfungsi untuk memberikan prioritas, menormalisasi, melakukan risk assesment, mengkoleksi, dan mengkorelasi perangkat perangkat lainnya.

b. Melakukan tugas-tugas eksternal dan perawatan seperti backup

scheduled, backup data, mengajukan atau melakukan penscanan dan inventory secara online.

3) Database, berfungsi melakukan penyimpanan data pada semua kejadian di suatu sistem jaringan sebagai informasi untuk manajemen sistem. Secara umum, Sistem pada OSSIM digambarkan pada Gambar 2 (Hadiansyah chandra and Iskandar, 2017).

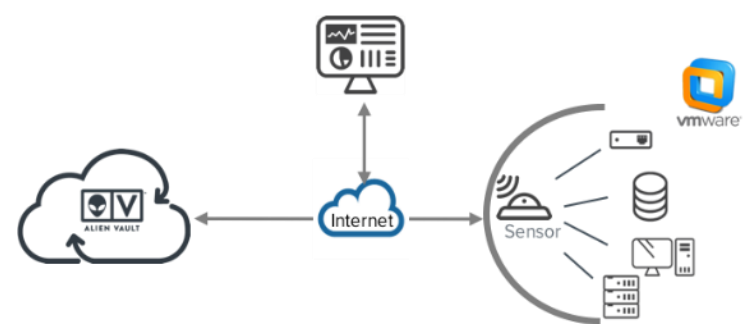

Gambar 2 Arsitektur OSSIM

\subsection{Alat Evaluasi Indeks KAMI}

Alat evaluasi Indeks KAMI dianjurkan untuk dilakukan oleh pejabat yang secara langsung bertanggung jawab dan berwenang untuk mengelola keamanan informasi di seluruh cakupan instansinya yang dijelaskan berdasarkan Gambar 3 .

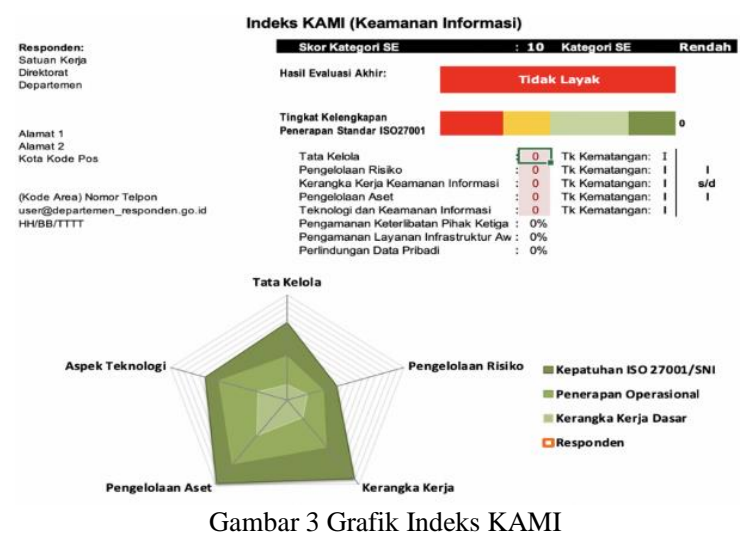

Berdasarkan Gambar 3, terkait grafik Indeks KAMI tentang evaluasi yang dilakukan dengan menggunakan indeks Keamanan Informasi (KAMI) ini mencakup 5 target area, yaitu:

\section{1) Tata Kelola Keamanan Informasi}

Pada bagian ini dilakukan evaluasi kesiapan bentuk tata kelola keamanan informasi beserta instansi/fungsi serta tugas dan tanggung jawab pengelola keamanan informasi. Kontrol yang diperlukan adalah kebijakan formal yang mendefinisikan peran, tanggung jawab, kewenangan pengelolaan keamanan informasi dari pimpinan unit kerja sampai ke pelaksana operasional. Termasuk juga adanya program 
kerja yang berkesinambungan, alokasi anggaran, evaluasi program dan strategi peningkatan kinerja tata kelola keamanan informasi.

\section{2) Pengelolaan Risiko Keamanan Informasi}

Pada bagian ini dilakukan evaluasi kesiapan penerapan pengelolaan risiko keamanan informasi sebagai dasar penerapan strategi keamanan informasi. Kontrol yang diberlakukan adalah adanya kerangka kerja pengelolaan risiko dengan definisi yang eksplisit terkait ambang batas diterimanya risiko, program pengelolaan risiko dan langkah mitigasi yang secara reguler dikaji keefektivitasanny

3) Kerangka Kerja Keamanan Informasi

Pada bagian ini dilakukan evaluasi kelengkapan dan kesiapan kerangka kerja (kebijakan \& prosedur) pengelolaan keamanan informasi dan strategi penerapannya. Kontrol yang diperlukan adalah sejumlah kebijakan dan prosedur kerja operasional, termasuk strategi penerapan, pengukuran efektivitas kontrol dan langkah perbaikan.

4) Pengelolaan Asset informasi

Pada bagian ini dilakukan evaluasi kelengkapan pengamanan terhadap asset informasi, termasuk keseluruhan siklus penggunaan asset tersebut. Kontrol yang diperlukan adalah bentuk pengamanan terkait keberadaan asset informasi serta keseluruhan proses yang bersifat teknis maupun administratif dalam siklus penggunaan asset tersebut

5) Teknologi dan Keamanan Informasi

Pada bagian ini dilakukan evaluasi kelengkapan, konsistensi, dan efektivitas penggunaan teknologi dalam pengamanan asset informasi. Kontrol yang digunakan adalah strategi terkait dengan tingkatan risiko dan tidak secara eksplisit menyebutkan teknologi atau merk tertentu.

Dari kelima aspek keamanan informasi berdasarkan indeks Keamanan Informasi (KAMI) maka peran IT dalam mengamankan informasinya dapat terukur dan bisa dijadikan sebagai inputan kepada pengelola layanan IT.

\subsection{Mengkaji Hasil Indeks KAMI}

Pada bagian ini akan dijelaskan hasil dari penilaian keseluruhan pada lima area keamanan informasi jaringan UIN Sunan Kalijaga Yogyakarta. Berikut dijelaskan dashboard pada hasil penilaian lima area keamanan informasi di Jaringan UIN Sunan Kalijaga.

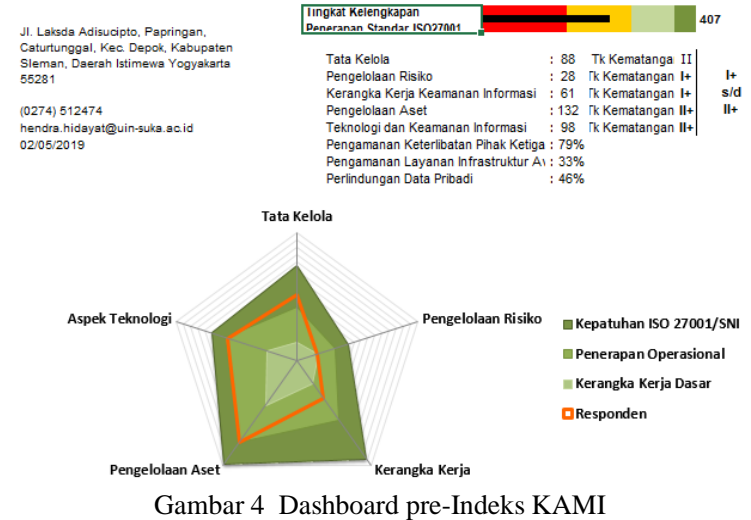

Pada Gambar 4, menunjukan tingkat kategori sistem elektronik yang digunakan oleh jaringan UIN Sunan Kalijaga Yogyakarta berada pada kategori yang Tinggi, dengan nilai 24. Dimana keberlangsungan proses kerja jaringan UIN Sunan Kalijaga Yogyakarta sangat bergantung besar pada penggunaan sistem elektronik. Sementara dari tingkat kelengkapan penerapan standar ISO 27001 berada pada level "Pemenuhan Kerangka Kerja Dasar" dengan level nilai 407, hal ini menunjukan tingginya ketergantungan instansi terhadap sistem elektronik namun tidak didukung dengan keamanan informasi yang memadai. Dengan hasil evaluasi akhir ini juga menunjukan bahwa jaringan UIN Sunan Kalijaga Yogyakarta membutuhkan perbaikan. Hal ini ditunjukkan dari tingkat kelayakan yang rata-rata menduduki level I+ dan II+ sehingga untuk kesiapan sertifikasi masih dikatakan belum layak sertifikasi keamanan informasi, karena untuk mencapai batas minimum kesiapan sertifikasi keamanan informasi adalah tingkat III.

Paparan terhadap hasil analisis forensik jaringan UIN Sunan Kalijaga Yogyakarta dilakukan setelah analisis dan simulasi, kemudian langkah berikutnya melakukan kuesioner ulang sebagai bentuk perbandingan apabila OSSIM di Implementasikan didalam Infrastruktur Jaringan UIN Sunan Kalijaga Yogyakarta. Peneliti melakukan post-assesment terhadap Jaringan UIN Sunan Kalijaga Yogyakarta dengan kuesioner indeks Keamanan Informasi (KAMI) untuk dapat mengukur nilai indeks Keamanan Informasi (KAMI) yang dimiliki oleh instansi tersebut.

Berdasarkan hasil analisis serangan dan korelasinya dengan OSSIM yang dilakukan dan dengan ketergantungan terhadap IT yang tinggi. Terlihat pada gambar 5 menunjukan bahwa nilai dari Jaringan UIN Sunan Kalijaga Yogyakarta adalah 432, yang menunjukan tingkat kelayakan keamanan informasi masih tetap di level I+ s/d II+, dan masih di level yang sama pada saat pre-assesment dilakukan, akan tetapi dari aspek tata kelola, asset dan teknologi menunjukan adanya kenaikan point nilai dari 407 menuju ke 432. 


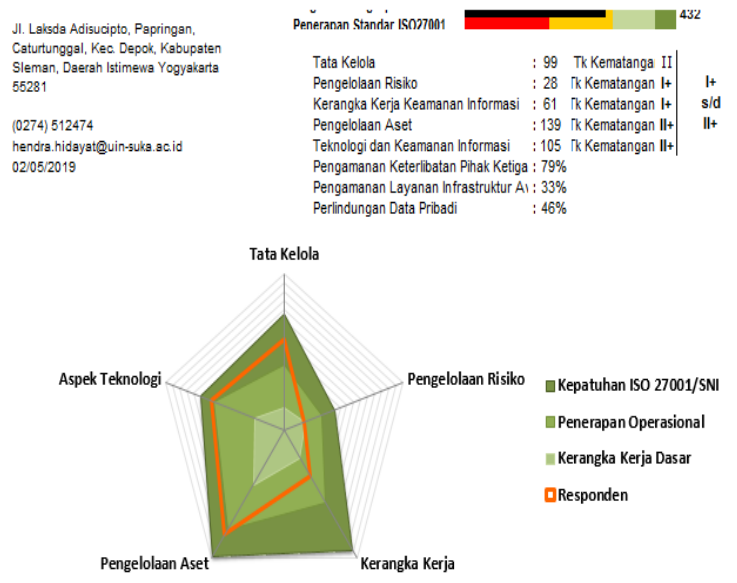

Gambar 5 Dashboard post-Indeks KAMI

Detail setiap aspek yang ada diukur dalam indeks dapat dilihat di grafik pada Gambar 5, terlihat tidak ada perbedaan untuk aspek management resiko, SOP, pengelolaan asset, tetapi terjadi perbedaan pada aspek tata kelola, asset dan teknologi yang menunjukan adanya kenaikan sebanyak 10,7 , dan 7 point dari preassesment yang dilakukan .

\subsection{Tata kelola Keamanan Informasi}

Tabel 1 Nilai Kelayakan Area Tata Kelola Keamanan Informasi

\begin{tabular}{lc}
\multicolumn{1}{c}{ Deskripsi } & Hasil \\
\hline Jumlah pertanyaan Tahap 1 & 8 \\
Jumlah pertanyaan Tahap 2 & 8 \\
Jumlah pertanyaan Tahap 3 & 6 \\
Batas Skor Min untuk Skor Tahap Penerapan 3 & 48 \\
Total Skor Tahap Penerapan 1 \& 2 & 57 \\
Status Peniliaian Tahap Penerapan 3 & Vali
\end{tabular}

Skor Tingkat Kematangan II

41

Skor Minimum Tingkat Kematangan II

Skor Pencapaian Tingkat Kematangan II

Status

Skor Tingkat Kematangan III

Validitas Tingkat Kematangan III

Skor Minimum Tingkat Kematangan III

Skor Pencapaian Tingkat Kematangan III

Status

Skor Tingkat Kematangan IV

Validitas Tingkat Kematangan IV

Skor Minimum Tingkat Kematangan IV

Skor Pencapaian Tingkat Kematangan IV

Status

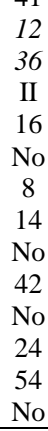

Tabel 2 Nilai Kelayakan Area Tata Kelola Keamanan Informasi

\begin{tabular}{lccccc}
\multicolumn{1}{c}{ (ii) } \\
\cline { 2 - 5 } \multicolumn{1}{c}{ Status Penerapan } & II & III & IV & V & \multirow{2}{*}{ Total } \\
\cline { 2 - 5 } & 0 & 0 & 0 & 0 & 0 \\
Tidak Dilakukan & 1 & 0 & 1 & 0 & 2 \\
$\begin{array}{l}\text { Dalam Perencanaan } \\
\text { Dalam }\end{array}$ & 11 & 1 & 4 & 0 & 16 \\
$\begin{array}{l}\text { Penerapan/Diterapkan } \\
\text { Sebagian }\end{array}$ & & & & & \\
$\begin{array}{l}\text { Diterapkan Secara } \\
\text { Menyeluruh }\end{array}$ & 1 & 2 & 1 & 0 & 4 \\
\hline Total & $\mathbf{1 3}$ & $\mathbf{3}$ & $\mathbf{6}$ & $\mathbf{0}$ & $\mathbf{2 2}$ \\
\hline
\end{tabular}

Nilai kelengkapan yang didapatkan tata kelola keamanan informasi adalah 88, Berdasarkan Tabel 1, diketahui jumlah pertanyaan pada tahap 1,2 dan 3 berturut-turut adalah 8,8 dan 6 dengan batas nilai minimal untuk nilai tahap penerapan 3 yaitu 48 dan total nilai tahap penerapan $1 \& 2$ yaitu 52 , sehingga status penilaian tahap penerapan 3 berstatus "Valid". Untuk nilai tingkat kelayakan II bernilai 36 dengan nilai minimum yaitu 12 serta nilai pencapaain bernilai 36 sehingga mendapat status "II". Selanjutnya untuk nilai tingkat kelayakan III bernilai 16 dengan validitas "No" serta nilai minimumnya bernilai 8 dan nilai pencapaain bernilai 14 sehingga mendapat status "No". selanjutnya untuk nilai tingkat kelayakan IV bernilai 36 dengan validitas "No" serta nilai minimum yaitu 24 dan nilai pencapaain bernilai 54 sehingga mendapat status "No".

Berdasarkan Tabel 2, terdapat 2 pertanyaan masing-masing pada tingkat kelayakan II dan IV yang telah direspon "Dalam Perencanaan". Selanjutnya pada status penerapan "Dalam Penerapan/Diterapkan Sebagian" terdapat 16 pertanyaan yang telah direspon masing-masing pada tingkat kelayakan II, III, dan IV berturut-turut adalah 11, 1, dan 4. Sedangkan pada status penerapan "Diterapkan Secara Menyeluruh" terdapat 4 pertanyaan yang telah direspon pada tingkat II, III dan IV masing-masing berturut-turut adalah 1, 2 dan 1. Berdasarkan hasil yang diperoleh diketahui bahwa pemahaman tentang keamanan informasi cukup besar dalam instansi, pengamanan informasi belum dipetakan lengkap dan terintegrasi, pengidentifikasian data pribadi, metrik dan parameter serta proses pengukuran kinerja masih proses perencanaan dan belum mendefinisikan kebijakan, langkah pidana insiden keamanan informasi dan beberapa masalah tata kelola keamanan informasi.

\subsection{Pengelolaan Risiko Keamanan Informasi}

Tabel 3 Nilai Kelayakan Area Pengelolaan Risiko Keamanan

\begin{tabular}{lc}
\multicolumn{1}{c}{ Informasi (i) } & Hasil \\
\hline Skor Tingkat Kematangan II & 16 \\
Skor Minimum Tingkat Kematangan II & 14 \\
Skor Pencapaian Tingkat Kematangan II & 20 \\
Status & $\mathrm{I}+$ \\
Skor Tingkat Kematangan III & 8 \\
Validitas Tingkat Kematangan III & $\mathrm{No}$ \\
Skor Minimum Tingkat Kematangan III & 4 \\
Skor Pencapaian Tingkat Kematangan III & 8 \\
Status & $\mathrm{No}$ \\
Skor Tingkat Kematangan IV & 4 \\
Validitas Tingkat Kematangan IV & No \\
Skor Minimum Tingkat Kematangan IV & 8 \\
Skor Pencapaian Tingkat Kematangan IV & 12 \\
Status & No \\
Skor Tingkat Kematangan V & 0 \\
Validitas Tingkat Kematangan V & No \\
Skor Minimum Tingkat Kematangan V & 12 \\
Skor Pencapaian Tingkat Kematangan V & 18 \\
Status & No \\
\hline
\end{tabular}


Tabel 4 Nilai Kelayakan Area Pengelolaan Risiko Keamanan Informasi (ii)

\begin{tabular}{lccccc}
\multicolumn{1}{c}{ Status Penerapan } & \multicolumn{4}{c}{ Tingkat Kelayakan } & \multirow{2}{*}{ Total } \\
\cline { 2 - 5 } & II & III & IV & V & \\
\hline Tidak Dilakukan & 0 & 0 & 0 & 0 & 0 \\
Dalam Perencanaan & 4 & 0 & 2 & 2 & 8 \\
$\begin{array}{l}\text { Dalam Penerapan/ } \\
\text { Diterapkan Sebagian }\end{array}$ & 6 & 2 & 0 & 0 & 8 \\
$\begin{array}{l}\text { Diterapkan Secara } \\
\text { Menyeluruh }\end{array}$ & 0 & 0 & 0 & 0 & 0 \\
\hline Total & $\mathbf{1 0}$ & $\mathbf{2}$ & $\mathbf{2}$ & $\mathbf{2}$ & $\mathbf{1 6}$ \\
\hline
\end{tabular}

Nilai kelengkapan yang didapatkan pengelolaan risiko keamanan informasi adalah 28 , Berdasarkan Tabel 3, diketahui jumlah pertanyaan pada tahap 1, 2 dan 3 berturut-turut adalah 10, 4 dan 2 dengan batas nilai minimal untuk nilai tahap penerapan 3 yaitu 36 dan total nilai tahap penerapan $1 \& 2$ yaitu 28 , sehingga status penilaian tahap penerapan 3 berstatus “ Tidak Valid". Untuk nilai tingkat kelayakan II bernilai 16 dengan nilai minimum yaitu 14 serta nilai pencapaain bernilai 20 sehingga mendapat status "I+". Selanjutnya untuk nilai tingkat kelayakan III bernilai 8 dengan validitas "No" serta nilai minimumnya bernilai 4 dan nilai pencapaain bernilai 8 sehingga mendapat status "No". selanjutnya untuk nilai tingkat kelayakan IV bernilai 4 dengan validitas "No" serta nilai minimum yaitu 8 dan nilai pencapaain bernilai 12 dengan status "No". selanjutnya untuk nilai tingkat kelayakan V bernilai 0 dengan validitas "No" serta nilai minimum yaitu 12 dan nilai pencapaain bernilai 18 sehingga mendapat status "No".

Berdasarkan Tabel 4, terdapat 8 pertanyaan pada tingkat kelayakan II, IV dan V yang di respon "Dalam Perencanaan" berturut-turut adalah 4, 2 dan 2 . Selanjutnya pada status penerapan "Dalam Penerapan/Diterapkan Sebagian" terdapat 8 pertanyaan yang telah direspon masing-masing pada tingkat kelayakan II dan III berturut-turut adalah 6 dan 2. Serta untuk tingkat kelayakan pada status penerapan "Diterapkan Secara Menyeluruh" tidak terdapat pertanyaan yang direspon. Berdasarkan hasil tersebut dapat diketahui pengelolaan risiko keamanan informasi sudah diterapkan sebagian, dokumentasi program kerja dan kerangka kerja pengelolaan risiko keamanan informasi belum diterapkan atau masih dalam perencanaan, dan beberapa masalah lain pengelolaan risiko keamanan informasi.

\subsection{Kerangka Kerja Pengelolaan Keamanan Informasi}

Tabel 5 nilai kelayakan area kerangka kerja keamanan informasi

\begin{tabular}{lc}
\multicolumn{1}{c}{ (i) } & \\
\hline Deskripsi & Hasil \\
\hline Jumlah pertanyaan Tahap 1 & 12 \\
Jumlah pertanyaan Tahap 2 & 10 \\
Jumlah pertanyaan Tahap 3 & 7 \\
Batas Skor Min untuk Skor Tahap Penerapan 3 & 64 \\
Total Skor Tahap Penerapan 1 \& 2 & 61
\end{tabular}

Status Peniliaian Tahap Penerapan 3

Tidak Valid

Skor Tingkat Kematangan II 18

\begin{tabular}{lc}
\hline \multicolumn{1}{c}{ Deskripsi } & Hasil \\
\hline Skor Minimum Tingkat Kematangan II & 15 \\
Skor Pencapaian Tingkat Kematangan II & 24 \\
Status & $\mathrm{I}+$ \\
Skor Tingkat Kematangan III & 43 \\
Validitas Tingkat Kematangan III & $\mathrm{No}$ \\
Skor Minimum Tingkat Kematangan III & 45 \\
Skor Pencapaian Tingkat Kematangan III & 62 \\
Status & $\mathrm{No}$ \\
Skor Tingkat Kematangan IV & 0 \\
Validitas Tingkat Kematangan IV & $\mathrm{No}$ \\
Skor Minimum Tingkat Kematangan IV & 15 \\
Skor Pencapaian Tingkat Kematangan IV & 27 \\
Status & $\mathrm{No}$ \\
Skor Tingkat Kematangan V & 0 \\
Validitas Tingkat Kematangan V & No \\
Skor Minimum Tingkat Kematangan V & 12 \\
Skor Pencapaian Tingkat Kematangan V & 18 \\
Status & No \\
\hline
\end{tabular}

Tabel 6 Nilai Kelayakan Area Kerangka Kerja Keamanan Informasi (ii)

\begin{tabular}{lccccc}
\hline \multirow{2}{*}{ Status Penerapan } & \multicolumn{4}{c}{ Tingkat Kelayakan } & \multirow{2}{*}{ Total } \\
\cline { 2 - 5 } & II & III & IV & V & \\
\hline Tidak Dilakukan & 0 & 0 & 0 & 0 & 0 \\
Dalam Perencanaan & 6 & 0 & 0 & 0 & 6 \\
$\begin{array}{l}\text { Dalam } \\
\text { Penerapan/Diterapkan }\end{array}$ & 5 & 9 & 3 & 2 & 19 \\
$\begin{array}{l}\text { Sebagian } \\
\begin{array}{l}\text { Diterapkan Secara } \\
\text { Menyeluruh }\end{array}\end{array}$ & 0 & 4 & 0 & 0 & 4 \\
\hline Total & 11 & 13 & 3 & 2 & 29 \\
\hline
\end{tabular}

Nilai kelengkapan yang didapatkan kerangka kerja pengelolaan keamanan informasi adalah 61 . Berdasarkan Tabel 5, diketahui jumlah pertanyaan pada tahap 1,2 dan 3 berturut-turut adalah 12, 10 dan 7 dengan batas nilai minimal untuk nilai tahap penerapan 3 yaitu 64 dan total nilai tahap penerapan $1 \& 2$ yaitu 61, sehingga status penilaian tahap penerapan 3 berstatus " Tidak Valid". Untuk nilai tingkat kelayakan II bernilai 18 dengan nilai minimum yaitu 15 serta nilai pencapaain bernilai 24 sehingga mendapat status "I+". Selanjutnya untuk nilai tingkat kelayakan III bernilai 43 dengan validitas "No" serta nilai minimumnya bernilai 45 dan nilai pencapaain bernilai 62 sehingga mendapat status "No". selanjutnya untuk nilai tingkat kelayakan IV bernilai 0 dengan validitas "No" serta nilai minimum yaitu 15 dan nilai pencapaain bernilai 27 dengan status "No". selanjutnya untuk nilai tingkat kelayakan $\mathrm{V}$ bernilai 0 dengan validitas "No" serta nilai minimum yaitu 12 dan nilai pencapaain bernilai 18 sehingga mendapat status "No".

Berdasarkan Tabel 6, terdapat 6 pertanyaan pada tingkat kelayakan II yang telah direspon "Dalam Perencanaan". Selanjutnya pada status penerapan "Dalam Penerapan/Diterapkan Sebagian" terdapat 19 pertanyaan yang telah direspon masing-masing pada tingkat kelayakan II, III, IV dan V berturut-turut adalah 5, 9, 3 dan 2. Sedangkan pada status penerapan "Diterapkan Secara Menyeluruh" terdapat 4 pertanyaan pada tingkat kelayakan III. Dari hasil tersebut diketahui bahwa keseluruhan dokumen kebijakan dan prosedur keamanan informasi masih dalam perencanaan, belum terdapat konsekuensi dan 
proses tindak lanjut terhadap pelanggaran, instansi belum menerapkan proses pengembangan sistem yang aman (secure SDLC), jaringan UIN Sunan Kalijaga Yogyakarta belum memiliki disaster recovery plan dikarenakan server berpusat pada satu gedung utama dan tidak terdapat Backup-an digedung lain serta beberapa masalah kerangka kerja pengelolaan keamanan informasi.

\subsection{Pengelolaan Asset Informasi}

Tabel 7 Nilai Kelayakan Area Pengelolaan Asset Informasi (i)

\begin{tabular}{lc}
\hline \multicolumn{1}{c}{ Deskripsi } & Hasil \\
\hline Jumlah pertanyaan Tahap 1 & 24 \\
Jumlah pertanyaan Tahap 2 & 10 \\
Jumlah pertanyaan Tahap 3 & 4 \\
Batas Skor Min untuk Skor Tahap Penerapan 3 & 88 \\
Total Skor Tahap Penerapan 1 \& 2 & 105 \\
Status Peniliaian Tahap Penerapan 3 & Valid \\
& \\
Skor Tingkat Kematangan II & 91 \\
Skor Minimum Tingkat Kematangan II & 25 \\
Skor Pencapaian Tingkat Kematangan II & 62 \\
Status & II \\
Skor Tingkat Kematangan III & 48 \\
Validitas Tingkat Kematangan III & Yes \\
Skor Minimum Tingkat Kematangan III & 35 \\
Skor Pencapaian Tingkat Kematangan III & 50 \\
Status & II+ \\
\hline
\end{tabular}

Tabel 8 Nilai Kelayakan Area Pengelolaan Asset (ii)

\begin{tabular}{lcccccc}
\hline \multirow{2}{*}{ Status Penerapan } & \multicolumn{5}{c}{ Tingkat Kelayakan } & \multirow{2}{*}{ Total } \\
\cline { 2 - 5 } & II & III & IV & V & \\
\hline Tidak Dilakukan & 0 & 0 & 0 & 0 & 0 \\
Dalam Perencanaan & 0 & 2 & 0 & 0 & 2 \\
$\begin{array}{l}\text { Dalam Penerapan/ } \\
\text { Diterapkan Sebagian }\end{array}$ & 14 & 5 & 0 & 0 & 19 \\
$\begin{array}{l}\text { Diterapkan Secara } \\
\text { Menyeluruh }\end{array}$ & 15 & 2 & 0 & 0 & 17 \\
\hline Total & 29 & 9 & 0 & 0 & 38 \\
\hline
\end{tabular}

Nilai kelengkapan yang didapatkan pada pengelolaan asset informasi adalah 132. Berdasarkan Tabel 7, diketahui jumlah pertanyaan pada tahap 1,2 dan 3 berturut-turut adalah 24, 10 dan 4 dengan batas nilai minimal untuk nilai tahap penerapan 3 yaitu 88 dan total nilai tahap penerapan $1 \& 2$ yaitu 98, sehingga status penilaian tahap penerapan 3 berstatus "Valid". Untuk nilai tingkat kelayakan II bernilai 86 dengan nilai minimum yaitu 25 serta nilai pencapaian bernilai 62 sehingga mendapat status "II". Selanjutnya untuk nilai tingkat kelayakan III bernilai 46 dengan validitas "Yes" serta nilai minimumnya bernilai 35 dan nilai pencapaain bernilai 50 sehingga mendapat status "II+".

Berdasarkan Tabel 8, terdapat 2 pertanyaan pada tingkat kelayakan III yang telah direspon "Dalam Perencanaan". Selanjutnya pada status penerapan "Dalam Penerapan/Diterapkan Sebagian" terdapat 19 pertanyaan yang telah direspon masing-masing pada tingkat kelayakan II dan III berturut-turut adalah 14 dan 5. Sedangkan pada status penerapan "Diterapkan Secara Menyeluruh" terdapat 17 pertanyaan yang telah direspon pada tingkat II dan III masing-masing berturut-turut adalah 15 dan 2. Berdasarkan hasil tersebut dapat diketahui jaringan UIN Sunan Kalijaga Yogyakarta sudah mengurus asset teknologi informasi cukup baik, dalam proses penerapan mitigasi risiko jaringan UIN Sunan Kalijaga Yogyakarta, belum melakukan ketetapan terkait pertukaran data dengan pihak eksternal dan pengamanannya, masih merencanakan prosedur penggunaan perangkat pengolah informasi yang dimiliki pihak ketiga serta beberapa masalah pengelolaan asset informasi.

\subsection{Teknologi dan Keamanan Informasi}

Tabel 9 Nilai Kelayakan Area Kerangka Teknologi Dan

\begin{tabular}{lc}
\multicolumn{2}{c}{ Keamanan Informasi (i) } \\
\hline \multicolumn{1}{c}{ Deskripsi } & Hasil \\
\hline Jumlah pertanyaan Tahap 1 & 14 \\
Jumlah pertanyaan Tahap 2 & 10 \\
Jumlah pertanyaan Tahap 3 & 2 \\
Batas Skor Min untuk Skor Tahap Penerapan 3 & 68 \\
Total Skor Tahap Penerapan 1 \& 2 & 87 \\
Status Peniliaian Tahap Penerapan 3 & Vali \\
& $d$
\end{tabular}

Skor Tingkat Kematangan II

Skor Minimum Tingkat Kematangan II

Skor Pencapaian Tingkat Kematangan II

Status

Skor Tingkat Kematangan III

Validitas Tingkat Kematangan III

Skor Minimum Tingkat Kematangan III

Skor Pencapaian Tingkat Kematangan III

Status

Skor Tingkat Kematangan IV

Validitas Tingkat Kematangan IV

Skor Minimum Tingkat Kematangan IV

Skor Pencapaian Tingkat Kematangan IV

Status

Tabel 10 Nilai Kelayakan Area Kerangka Teknologi Dan Keamanan Informasi (ii)

\begin{tabular}{|c|c|c|c|c|c|}
\hline \multirow{2}{*}{ Status Penerapan } & \multicolumn{4}{|c|}{ Tingkat Kelayakan } & \multirow{2}{*}{ Total } \\
\hline & II & III & IV & $\mathrm{V}$ & \\
\hline Tidak Dilakukan & 0 & 0 & 0 & 0 & 0 \\
\hline Dalam Perencanaan & 0 & 1 & 0 & 0 & 1 \\
\hline $\begin{array}{l}\text { Dalam Penerapan/ } \\
\text { Diterapkan Sebagian }\end{array}$ & 4 & 3 & 1 & 0 & 8 \\
\hline $\begin{array}{l}\text { Diterapkan Secara } \\
\text { Menyeluruh }\end{array}$ & 10 & 5 & 0 & 0 & 15 \\
\hline Total & 14 & 11 & 1 & 0 & 26 \\
\hline
\end{tabular}

Nilai kelengkapan yang didapatkan teknologi dan keamanan informasi adalah 98. Berdasarkan Tabel 9, diketahui jumlah pertanyaan pada tahap 1,2 dan 3 berturut-turut adalah 14, 10 dan 2 dengan batas nilai minimal untuk nilai tahap penerapan 3 yaitu 68 dan total nilai tahap penerapan $1 \& 2$ yaitu 86 , sehingga status penilaian tahap penerapan 3 berstatus "Valid". Untuk nilai tingkat kelayakan II bernilai 38 dengan nilai minimum yaitu 18 serta nilai pencapaain bernilai 28 sehingga mendapat status "II". Selanjutnya untuk nilai tingkat kelayakan III bernilai 54 dengan validitas "Yes" serta nilai minimumnya bernilai 40 dan nilai pencapaain bernilai 62 sehingga mendapat status "II+". selanjutnya untuk nilai tingkat kelayakan IV bernilai 6 dengan validitas "No" serta 
nilai minimum yaitu 6 dan nilai pencapaain bernilai 9 dengan status "No".

Berdasarkan Tabel 10 terdapat 1 pertanyaan pada tingkat kelayakan III yang telah direspon "Dalam Perencanaan". Selanjutnya pada status penerapan "Dalam Penerapan/Diterapkan Sebagian" terdapat 8 pertanyaan yang telah direspon masing-masing pada tingkat kelayakan II, III dan IV berturut-turut adalah 4, 3 dan 1. Sedangkan pada status penerapan "Diterapkan Secara Menyeluruh" terdapat 15 pertanyaan yang telah direspon pada tingkat II dan III masing-masing berturut-turut adalah 10 dan 5 . Berdasarkan hasil tersebut dapat diketahui yaitu penggunaan internet pada layanan TIK telah dilindungi pengamanan berlapis, tersedia konfigurasi standar keamanan sistem, adanya standar penggunaan enskripsi, instansi memiliki rekaman analisa yang mengkonfirmasi antivirus/malware telah dimutakhirkan dan beberapa masalah teknologi dan keamanan informasi lainnya.

Berikut hasil tingkat kelayakan untuk seluruh area berdasarkan tingkat validitas nilai.

\begin{tabular}{|c|c|c|c|c|c|}
\hline & $\begin{array}{l}\text { Tata } \\
\text { Kelo } \\
\text { la }\end{array}$ & $\begin{array}{l}\text { Peng } \\
\text { elola } \\
\text { an } \\
\text { Risi } \\
\text { ko } \\
\end{array}$ & $\begin{array}{l}\text { Kera } \\
\text { ngka } \\
\text { Kerj } \\
\text { a }\end{array}$ & $\begin{array}{l}\text { Peng } \\
\text { elola } \\
\text { an } \\
\text { Asset }\end{array}$ & $\begin{array}{l}\text { Aspe } \\
\text { k } \\
\text { Tek } \\
\text { nolo } \\
\text { gi } \\
\end{array}$ \\
\hline \multicolumn{6}{|l|}{ Tingkat II } \\
\hline $\begin{array}{c}\text { Status } \\
\text { Tingkat III }\end{array}$ & \multicolumn{5}{|c|}{ Tingkat III } \\
\hline Validitas & No & No & No & Yes & Yes \\
\hline Status & No & No & No & II+ & II+ \\
\hline \multicolumn{6}{|l|}{ Tingkat IV } \\
\hline Validitas & No & No & No & No & No \\
\hline Status & No & No & No & No & No \\
\hline \multicolumn{6}{|l|}{ Tingkat V } \\
\hline Validitas & No & No & No & No & No \\
\hline Status & No & No & No & No & No \\
\hline Status Akhir & II & I+ & $\mathrm{I}+$ & II+ & II+ \\
\hline & 3 & 2 & 2 & 4 & 4 \\
\hline
\end{tabular}

Berdasarkan Tabel 11 diketahui bahwa status kelayakan lima area keamanan informasi untuk status keamanan informasi berada tingkat II bernilai "II" pada aspek tata kelola, pengelolaan asset dan aspek teknologi serta "I+" pada aspek pengelolaan risiko dan aspek kerangka kerja. Hal ini membuktikan bahwa nilai yang didapatkan hampir memenuhi syarat untuk masuk pada level kelayakan III. Pada tingkat III untuk aspek pengelolaan asset dan aspek teknologi memiliki validitas "Yes" dengan status "II+" sedangkan pada aspek lain memiliki validitas "No". Untuk Tingkat IV dan V masih memiliki validitas "No", dapat mencapai tingkat kelayakan III pada syarat indeks KAMI apabila sebagian besar ditingkat kelayakan sebelumnya rumus standar Keamanan Informasi [x-1] dengan indikator sudah “Diterapkan Secara Menyeluruh".Sedangkan sebagai paduan standar ISO/IEC 27001:2005, tingkat kelayakan yang diharapkan untuk ambang batas minimum kesiapan sertifikasi adalah tingkat III+.

\begin{tabular}{ccc}
\multicolumn{3}{c}{ Tabel 12 Trafik Protokol TCP } \\
\hline Tanggal & Jam Kerja & Bukan Jam Kerja \\
\hline $\mathbf{1 6}$ & $98,92 \mathrm{~kb} / \mathrm{s}$ & $218,02 \mathrm{~kb} / \mathrm{s}$ \\
$\mathbf{1 7}$ & $28,04 \mathrm{~kb} / \mathrm{s}$ & $226,72 \mathrm{~kb} / \mathrm{s}$ \\
$\mathbf{1 8}$ & $26,95 \mathrm{~kb} / \mathrm{s}$ & $214,57 \mathrm{~kb} / \mathrm{s}$ \\
$\mathbf{1 9}$ & $58,41 \mathrm{~kb} / \mathrm{s}$ & $202,89 \mathrm{~kb} / \mathrm{s}$ \\
$\mathbf{2 0}$ & $42,75 \mathrm{~kb} / \mathrm{s}$ & $216,15 \mathrm{~kb} / \mathrm{s}$ \\
$\mathbf{2 1}$ & $29,68 \mathrm{~kb} / \mathrm{s}$ & $194,01 \mathrm{~kb} / \mathrm{s}$ \\
$\mathbf{2 2}$ & $36,14 \mathrm{~kb} / \mathrm{s}$ & $196,6 \mathrm{~kb} / \mathrm{s}$ \\
\hline & & \\
\hline Tanggal & Tabel 13 Trafik Protokol UDP \\
\hline $\mathbf{1 6}$ & Jam Kerja & Bukan Jam Kerja \\
$\mathbf{1 7}$ & $32,44 \mathrm{~kb} / \mathrm{s}$ & $13,92 \mathrm{~kb} / \mathrm{s}$ \\
$\mathbf{1 8}$ & $24,28 \mathrm{~kb} / \mathrm{s}$ & $12,97 \mathrm{~kb} / \mathrm{s}$ \\
$\mathbf{1 9}$ & $19,81 \mathrm{~kb} / \mathrm{s}$ & $14,95 \mathrm{~kb} / \mathrm{s}$ \\
$\mathbf{2 0}$ & $22,65 \mathrm{~kb} / \mathrm{s}$ & $13,31 \mathrm{~kb} / \mathrm{s}$ \\
$\mathbf{2 1}$ & $21,31 \mathrm{~kb} / \mathrm{s}$ & $14,07 \mathrm{~kb} / \mathrm{s}$ \\
$\mathbf{2 2}$ & $17,05 \mathrm{~kb} / \mathrm{s}$ & $11,52 \mathrm{~kb} / \mathrm{s}$ \\
& $18,72 \mathrm{~kb} / \mathrm{s}$ & $14,18 \mathrm{~kb} / \mathrm{s}$ \\
\hline & Tabel 14 Trafik Protokol ICMP \\
\hline Tanggal & Jam Kerja & Bukan Jam Kerja \\
\hline $\mathbf{1 6}$ & $24,62 \mathrm{~b} / \mathrm{s}$ & $33,64 \mathrm{~b} / \mathrm{s}$ \\
$\mathbf{1 7}$ & $22,41 \mathrm{~b} / \mathrm{s}$ & $30,76 \mathrm{~b} / \mathrm{s}$ \\
$\mathbf{1 8}$ & $18,62 \mathrm{~b} / \mathrm{s}$ & $24,18 \mathrm{~b} / \mathrm{s}$ \\
$\mathbf{1 9}$ & $20,52 \mathrm{~b} / \mathrm{s}$ & $25,91 \mathrm{~b} / \mathrm{s}$ \\
$\mathbf{2 0}$ & $23,68 \mathrm{~b} / \mathrm{s}$ & $28,99 \mathrm{~b} / \mathrm{s}$ \\
$\mathbf{2 1}$ & $19,61 \mathrm{~b} / \mathrm{s}$ & $30,62 \mathrm{~b} / \mathrm{s}$ \\
& $22,58 \mathrm{~b} / \mathrm{s}$ & $32,44 \mathrm{~b} / \mathrm{s}$ \\
\hline & & \\
\hline
\end{tabular}

Sistem deteksi berdasarkan anomali dengan mengamati aktivitas-aktivitas trafik jaringan yang menyimpang secara signifikan dari penggunaan trafik normal. Sistem ini menggangap sesuatu yang tidak normal sebagai anomali. Kontruksi jaringan dari sistem deteksi ini dimulai dengan membangun model kondisi normal dan jaringan yang diamati yang kemudian dilanjutkan sebagai kondisi abnormal. Kelebihan dari sistem deteksi berdasarkan anomali adalah tidak perlunya pemahaman mendalam tentang malware dan dapat mendeteksi serangan berupa malware yang baru. Kekurangannya adalah tidak dapat diketahui tipe serangan apa yang menyerang jaringan. Open Souce SIEM(OSSIM) memiliki kemampuan untuk melakukan pengamatan trafik jaringan seperti pengamatan trafik protokol. Pada penelitian ini langkah selanjutnya adalah melakukan monitoring dan pengambilan data trafik protokol pada sistem jaringan di UIN Sunan Kalijaga Yogyakarta. selama satu minggu dari tanggal 16 September 2019 sampai tanggal 22 September 2019 dan pengamatan dilakukan pada jam kerja pad pukul 08.00- 16.00 dan bukan jam kerja pada pukul 16.0008.00 . Adapun data yang diambil adalah nilai ratarata dari protokol TCP, UDP dan ICMP. Data hasil pengamatan trafik TCP, UDP dan ICMP bisa di lihat pada Tabel 12, Tabel 13 dan Tabel 14.

Tujuan pengambilan data ini adalah untuk menganalisa kondisi keamanan dan jaringan, dengan cara memonitoring perubahan trafik jaringan. Dari data pengamatan didapatkan bahwa kondisi jaringan dari ketiga protokol saat jam kerja lebih kecil dibandingkan dengan Bukan Jam kerja. 
1146 Jurnal Teknologi Informasi dan Ilmu Komputer (JTIIK), Vol. 8, No. 6, Desember 2021, hlm. 1137-1148

\begin{tabular}{cccc}
\multicolumn{4}{c}{ Tabel 15 Rata-rata Trafik Protokol } \\
\hline Protokol & Jam Kerja & Bukan Jam Kerja & Selisih \\
\hline TCP & $45,84 \mathrm{~kb} / \mathrm{s}$ & $209,85 \mathrm{~kb} / \mathrm{s}$ & 164,01 \\
UDP & $22,32 \mathrm{~kb} / \mathrm{s}$ & $13,56 \mathrm{~kb} / \mathrm{s}$ & 8,76 \\
ICMP & $21,72 \mathrm{~b} / \mathrm{s}$ & $29,49 \mathrm{~b} / \mathrm{s}$ & 7,77 \\
\hline
\end{tabular}

Dari data yang ada pada Tabel 15 dapat diambil kesimpulan bahwa rata-rata trafik TCP lebih besar $164,01 \mathrm{~kb} / \mathrm{s}$ pada saat bukan jam kerja, rata-rata trafik UDP lebih besar $8,76 \mathrm{~kb} / \mathrm{s}$ pada saat jam kerja dan rata-rata ICMP lebih besar $9,63 \mathrm{~b} / \mathrm{s}$ pada saat bukan jam kerja.

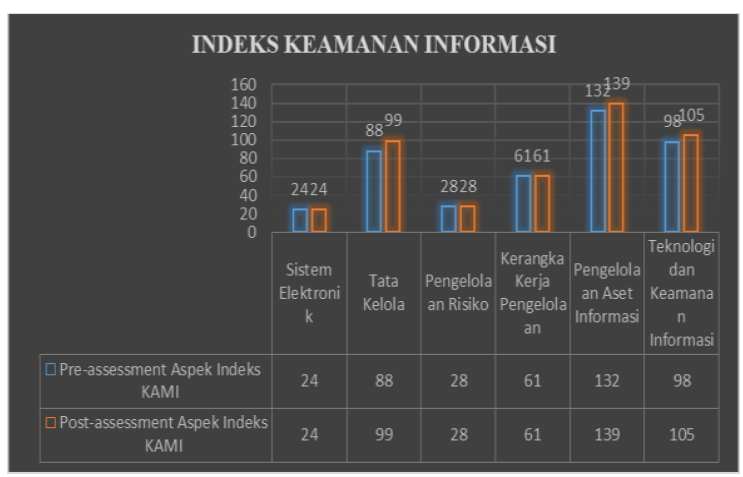

Gambar 6 Nilai indeks (KAMI) Pre-Assessment dan Post-Assessment Jaringan UIN Sunan Kalijaga Yogyakarta

Berdasarkan Gambar 6, penyebab kenaikan nilai indeks Keamanan Informasi (KAMI) dari beberapa aspek tata kelola, pengelolaan asset informasi dan teknologi keamanan informasi yang dipengaruhi oleh beberapa point yang ditunjukan pada Tabel 16, Tabel 17, Tabel 18, Tabel 19, Tabel 20, Tabel 21.

Tabel 16 Aspek "Tata kelola Keamanan Informasi” Pre-

\begin{tabular}{|c|c|c|c|}
\hline No & $\begin{array}{l}\text { Evaluasi Tata Kelola } \\
\text { Keamanan Informasi }\end{array}$ & Status & $\begin{array}{c}\text { Poin } \\
t\end{array}$ \\
\hline 1 & $\begin{array}{l}\text { Apakah instansi/perusahaan } \\
\text { pada jaringan Keamanan } \\
\text { Informasi di UIN Sunan } \\
\text { Kalijaga Yogyakarta sudah } \\
\text { menerapkan peningkatan } \\
\text { pemahaman dan program } \\
\text { sosialisasi untuk keamanan } \\
\text { informasi,termasuk kepentingan } \\
\text { kepatuhannya bagi semua pihak } \\
\text { yang terkait? }\end{array}$ & $\begin{array}{l}\text { Dalam } \\
\text { Penerapan/ } \\
\text { Diterapkan } \\
\text { Sebagian }\end{array}$ & 2 \\
\hline 2 & $\begin{array}{l}\text { Apakah instansi/perusahaan } \\
\text { anda menerapkan program } \\
\text { peningkatan kompetensi dan } \\
\text { keahlian untuk pejabat dan } \\
\text { petugas pelaksana pengelolaan } \\
\text { keamanan informasi? }\end{array}$ & $\begin{array}{l}\text { Dalam } \\
\text { Penerapan/ } \\
\text { Diterapkan } \\
\text { Sebagian }\end{array}$ & 4 \\
\hline 3 & $\begin{array}{l}\text { Apakah instansi/perusahaan } \\
\text { anda sudah mengintegrasikan } \\
\text { keperluan/persyaratan } \\
\text { keamanan informasi dalam } \\
\text { proses kerja yang ada? }\end{array}$ & $\begin{array}{l}\text { Dalam } \\
\text { Penerapan/ } \\
\text { Diterapkan } \\
\text { Sebagian }\end{array}$ & 4 \\
\hline 4 & $\begin{array}{l}\text { Apakah instansi/perusahaan } \\
\text { anda sudah mendefinisikan } \\
\text { metrik, paramater dan proses } \\
\text { pengukuran kinerja pengelolaan } \\
\text { keamanan informasi yang } \\
\text { mencakup mekanisme, waktu } \\
\text { pengukuran, pelaksananya, }\end{array}$ & $\begin{array}{l}\text { Dalam } \\
\text { Penerapan/ } \\
\text { Diterapkan } \\
\text { Sebagian }\end{array}$ & 6 \\
\hline
\end{tabular}

\begin{tabular}{|c|c|c|c|}
\hline No & $\begin{array}{l}\text { Evaluasi Tata Kelola } \\
\text { Keamanan Informasi }\end{array}$ & Status & $\begin{array}{c}\text { Poin } \\
t\end{array}$ \\
\hline & $\begin{array}{l}\text { pemantauannya dan eskalasi } \\
\text { pelaporannya? }\end{array}$ & & \\
\hline 5 & $\begin{array}{l}\text { Apakah instansi/perusahaan } \\
\text { anda sudah menerapkan } \\
\text { program penilaian kinerja } \\
\text { pengelolaan keamanan } \\
\text { informasi bagi individu (pejabat } \\
\text { \& petugas) pelaksananya? }\end{array}$ & $\begin{array}{l}\text { Dalam } \\
\text { Penerapan/ } \\
\text { Diterapkan } \\
\text { Sebagian }\end{array}$ & 6 \\
\hline
\end{tabular}

Tabel 17 Aspek “Tata kelola Keamanan Informasi” post-

\begin{tabular}{|c|c|c|c|}
\hline No & $\begin{array}{l}\text { Evaluasi Tata Kelola } \\
\text { Keamanan Informasi }\end{array}$ & Status & Point \\
\hline 1 & $\begin{array}{l}\text { Apakah jaringan UIN Sunan } \\
\text { Kalijaga Yogyakarta sudah } \\
\text { menerapkan peningkatan } \\
\text { pemahaman dan program } \\
\text { sosialisasi untuk keamanan } \\
\text { informasi, rermasuk } \\
\text { kepentingan tingkat ketaatan } \\
\text { bagi semua pihak yang terkait? }\end{array}$ & $\begin{array}{l}\text { Diterapkan } \\
\text { Secara } \\
\text { Menyeluruh }\end{array}$ & 3 \\
\hline 2 & $\begin{array}{l}\text { Apakah jaringan UIN Sunan } \\
\text { Kalijaga Yogyakarta anda } \\
\text { menerapkan program keahlian } \\
\text { dan peningkatan kompetensi } \\
\text { untuk petugas dan pejabat } \\
\text { pelaksana pengelolaan } \\
\text { keamanan informasi? }\end{array}$ & $\begin{array}{l}\text { Diterapkan } \\
\text { Secara } \\
\text { Menyeluruh }\end{array}$ & 6 \\
\hline 3 & $\begin{array}{l}\text { Apakah jaringan UIN Sunan } \\
\text { Kalijaga Yogyakarta anda } \\
\text { sudah mengintegrasikan } \\
\text { persyaratan/ keperluan } \\
\text { keamanan informasi pada } \\
\text { proses kerja yang ada? }\end{array}$ & $\begin{array}{l}\text { Diterapkan } \\
\text { Secara } \\
\text { Menyeluruh }\end{array}$ & 6 \\
\hline 4 & $\begin{array}{l}\text { Apakah jaringan UIN Sunan } \\
\text { Kalijaga Yogyakarta anda } \\
\text { sudah mendefinisikan proses, } \\
\text { metrik, dan parameter pada } \\
\text { pengukuran } \\
\text { pengelolaan kinerja } \\
\text { informasi yang mencakup } \\
\text { waktu, pengukuran, waktu } \\
\text { mekanisme, pemantauannya, } \\
\text { pelaporannya, dan eskalasi } \\
\text { pelaksananya? }\end{array}$ & $\begin{array}{l}\text { Diterapkan } \\
\text { Secara } \\
\text { Menyeluruh }\end{array}$ & 9 \\
\hline 5 & $\begin{array}{l}\text { Apakah jaringan UIN Sunan } \\
\text { Kalijaga Yogyakarta anda } \\
\text { sudah menerapkan program } \\
\text { penilaian kinerja pengelolaan } \\
\text { keamanan informasi bagi } \\
\text { individu (petugas dan pejabat) } \\
\text { pelaksananya? }\end{array}$ & $\begin{array}{l}\text { Diterapkan } \\
\text { Secara } \\
\text { Menyeluruh }\end{array}$ & 9 \\
\hline
\end{tabular}

Tabel 18 Aspek "Pengelolaan Asset Informasi" Pre-Assesment

\begin{tabular}{|c|c|c|c|}
\hline No & $\begin{array}{c}\text { Evaluasi Pengelolaan Asset } \\
\text { Informasi }\end{array}$ & Status & $\begin{array}{c}\text { Poin } \\
t\end{array}$ \\
\hline 1 & $\begin{array}{l}\text { Definisi tanggungjawab } \\
\text { pengamanan informasi secara } \\
\text { individual untuk semua personil } \\
\text { di instansi/perusahaan anda }\end{array}$ & $\begin{array}{l}\text { Dalam } \\
\text { Penerapan/ } \\
\text { Diterapkan } \\
\text { Sebagian }\end{array}$ & 2 \\
\hline 2 & $\begin{array}{l}\text { Prosedur } \quad \text { penghancuran } \\
\text { datalasset yang sudah tidak } \\
\text { diperlukan }\end{array}$ & $\begin{array}{l}\text { Dalam } \\
\text { Perencanaan }\end{array}$ & 2 \\
\hline 3 & $\begin{array}{l}\text { Apakah tersedia proses untuk } \\
\text { memeriksa (inspeksi) dan } \\
\text { merawat: perangkat komputer, } \\
\text { fasilitas pendukungnya dan } \\
\text { kelayakan keamanan lokasi } \\
\text { kerja untuk menempatkan asset } \\
\text { informasi penting? }\end{array}$ & $\begin{array}{l}\text { Dalam } \\
\text { Penerapan/ } \\
\text { Diterapkan } \\
\text { Sebagian }\end{array}$ & 4 \\
\hline
\end{tabular}




\begin{tabular}{|c|c|c|c|}
\hline No & $\begin{array}{c}\text { Evaluasi Pengelolaan Asset } \\
\text { Informasi }\end{array}$ & Status & $\begin{array}{c}\text { Poin } \\
t\end{array}$ \\
\hline 4 & $\begin{array}{l}\text { Apakah tersedia mekanisme } \\
\text { pengamanan dalam pengiriman } \\
\text { asset informasi (perangkat dan } \\
\text { dokumen) yang melibatkan } \\
\text { pihak ketiga? }\end{array}$ & $\begin{array}{l}\text { Dalam } \\
\text { Penerapan/ } \\
\text { Diterapkan } \\
\text { Sebagian }\end{array}$ & 4 \\
\hline
\end{tabular}

Tabel 19 Aspek "Pengelolaan Asset Informasi" Post-Assesment

\begin{tabular}{|c|c|c|c|}
\hline No & $\begin{array}{c}\text { Evaluasi Pengelolaan Asset } \\
\text { Informasi }\end{array}$ & Status & Point \\
\hline 1 & $\begin{array}{lr}\text { Definisi tanggungjawab } \\
\text { pengamanan informasi secara } \\
\text { individual untuk semua } \\
\text { personil } \\
\text { instansi/perusahaan anda }\end{array}$ & $\begin{array}{l}\text { Diterapkan } \\
\text { Secara } \\
\text { Menyeluruh }\end{array}$ & 3 \\
\hline 2 & $\begin{array}{l}\text { Prosedur penghancuran } \\
\text { datalasset yang sudah tidak } \\
\text { diperlukan }\end{array}$ & $\begin{array}{l}\text { Dalam } \\
\text { Perencanaan }\end{array}$ & 2 \\
\hline 3 & $\begin{array}{l}\text { Apakah tersedia proses pada } \\
\text { jaringan UIN Sunan Kalijaga } \\
\text { Yogyakarta untuk merawat } \\
\text { perangkat computer, } \\
\text { kelayakan keamanan lokasi } \\
\text { kerja, memeriksa (inspeksi), } \\
\text { fasilitas pendukungnya untuk } \\
\text { menempatkan asset informasi } \\
\text { yang penting? }\end{array}$ & $\begin{array}{l}\text { Diterapkan } \\
\text { Secara } \\
\text { Menyeluruh }\end{array}$ & 6 \\
\hline 4 & $\begin{array}{l}\text { Apakah tersedia mekanisme } \\
\text { pada jaringan UIN Sunan } \\
\text { Kalijaga, pengamanan pada } \\
\text { pengiriman asset informasi } \\
\text { (dokumen dan perangkat) } \\
\text { yang melibatkan pihak } \\
\text { ketiga? }\end{array}$ & $\begin{array}{l}\text { Diterapkan } \\
\text { Secara } \\
\text { Menyeluruh }\end{array}$ & 6 \\
\hline
\end{tabular}

Tabel 20 Aspek “Teknologi dan Keamanan Informasi” PreAssesment

\begin{tabular}{|c|c|c|c|}
\hline No & $\begin{array}{c}\text { Evaluasi Teknologi dan } \\
\text { Keamanan Informasi }\end{array}$ & Status & $\begin{array}{c}\text { Poin } \\
t\end{array}$ \\
\hline $\mathbf{1}$ & $\begin{array}{l}\text { Apakah sistem operasi untuk } \\
\text { setiap perangkat desktop dan } \\
\text { server dimutakhirkan dengan } \\
\text { versi terkini? }\end{array}$ & $\begin{array}{l}\text { Dalam } \\
\text { Penerapan/ } \\
\text { Diterapkan } \\
\text { Sebagian }\end{array}$ & 2 \\
\hline 2 & $\begin{array}{l}\text { Apakah instansi/perusahaan ada } \\
\text { menerapkan lingkungan } \\
\text { pengembangan dan uji coba } \\
\text { yang sudah diamankan sesuai } \\
\text { dengan standar platform } \\
\text { teknologi yang ada dan } \\
\text { digunakan untuk seluruh siklus } \\
\text { hidup sistem yng dibangun? }\end{array}$ & $\begin{array}{l}\text { Dalam } \\
\text { Penerapan/ } \\
\text { Diterapkan } \\
\text { Sebagian }\end{array}$ & 6 \\
\hline 3 & $\begin{array}{l}\text { Apakah instansi/perusahaan } \\
\text { anda melibatkan pihak } \\
\text { independen untuk mengkaji } \\
\text { kehandalan keamanan informasi } \\
\text { secara rutin? }\end{array}$ & $\begin{array}{l}\text { Dalam } \\
\text { Penerapan/ } \\
\text { Diterapkan } \\
\text { Sebagian }\end{array}$ & 6 \\
\hline
\end{tabular}

Tabel 21 Aspek “Teknologi dan Keamanan Informasi” PostAssesment

\begin{tabular}{|c|c|c|c|}
\hline No & $\begin{array}{l}\text { Evaluasi Teknologi dan } \\
\text { Keamanan Informasi }\end{array}$ & Status & Point \\
\hline $\mathbf{1}$ & $\begin{array}{l}\text { Apakah sistem operasi } \\
\text { untuk setiap perangkat } \\
\text { desktop dan server hirkan } \\
\text { dengan versi terkini? }\end{array}$ & $\begin{array}{l}\text { Diterapkan } \\
\text { Secara } \\
\text { Menyeluruh }\end{array}$ & 3 \\
\hline 2 & $\begin{array}{l}\text { Apakah jaringan pada UIN } \\
\text { Sunan Kalijaga Yogyakarta } \\
\text { anda menerapkan uji coba } \\
\text { dan lingkungan } \\
\text { pengembangan yang sudah } \\
\text { diamankan sesuai dengan }\end{array}$ & $\begin{array}{l}\text { Diterapkan } \\
\text { Secara } \\
\text { Menyeluruh }\end{array}$ & 9 \\
\hline
\end{tabular}

\begin{tabular}{lllc}
\hline No & $\begin{array}{c}\text { Evaluasi Teknologi dan } \\
\text { Keamanan Informasi }\end{array}$ & Status & Point \\
\hline & digunakan untuk seluruh & & \\
siklus hidup sistem yng & & \\
dibangun dan standar & & \\
& platform teknologi yang & & \\
ada? & Apakah jaringan UIN Sunan & Diterapkan & 9 \\
& Kalijaga anda melibatkan & Secara & \\
& pihak independen untuk & Menyeluruh & \\
& mengkaji kehandalan & & \\
& keamanan informasi secara & \\
rutin? & \\
\hline
\end{tabular}

Hasil perbandingan diatas yang merupakan hasil dari kuesioner tersebut, kemudian dihitung sesuai dengan format aplikasi yang dimiliki oleh Direktorat Keamanan Informasi Kementerian Komunikasi dan Informatika Indonesia dan menujukan bahwa penggunaan Open Souce SIEM(OSSIM) dapat membantu menaikan nilai point untuk aspek Teknologi yang ada pada indeks Keamanan Informasi (KAMI) akan tetapi tidak berpengaruh pada aspekaspek yang lain. Terlihat bahwa nilai dari Jaringan UIN Sunan Kalijaga Yogyakarta adalah 432 pada Gambar 5, dari sebelummnya adalah 407 point pada Gambar 4, yang menunjukan tingkat kelayakan keamanan informasi masih di I+ s/d II+, masih di level yang sama pada saat pre-assesment dilakukan, akan tetapi dari aspek tata kelola menunjukan adanya perubahan nilai dari 88 menuju ke 99, pengelolaan asset menunjukan adanya perubahan nilai dari 132 menuju ke 139, dan teknologi menunjukan adanya perubahan nilai dari 98 menuju ke 105 yang dijelaskan pada Gambar 6. Dengan memonitor kondisi jaringan UIN Sunan Kalijaga Yogyakarta dapat diperoleh tujuan dari penelitian ini, yakni memantau dan mengetahui lebih detail permasalahan yang ada pada Jaringan UIN Sunan Kalijaga Yogyakarta sehingga dapat diketahui pola solusi untuk mengatasinya sehingga dapat memaksimalkan infrastruktur jaringan komputer yang ada dengan lebih efektif dan efisien sesuai fungsinya sebagai institusi pendidikan.

\section{KESIMPULAN}

Data indeks Keamanan Informasi (KAMI) didapatkan melalui pengisian kuesioner mengenai Evaluasi Manajemen Keamanan Informasi pada Jaringan UIN Sunan Kalijaga Yogyakarta selanjutnya hasil kuesioner baru dibandingkan dengan hasil kuesioner sebelumnya. Berdasarkan tingkat kelengkapan dan kelayakan nilai indeks KAMI yang diujikan pada jaringan UIN Sunan Kalijaga Yogyakarta masih rendah. Penyebab rendahnya tingkat kelengkapan dan kelayakan keamanan informasi ini adalah jaringan UIN Sunan Kalijaga Yogyakarta belum menerapkan semua syarat keamanan informasi atau masih dalam perencanaan. Dalam hubungannya dengan indeks KAMI pengunaan teknologi Open Source SIEM (OSSIM) terbukti dapat menaikan nilai indeks KAMI Jaringan 
UIN Sunan Kalijaga Yogyakarta pada berbagai aspek, adapun kenaikan ini karena kemampuan OSSIM dalam menganalisa kelemahan dan perubahan konfigurasi asset informasi di jaringan UIN Sunan Kalijaga Yogyakarta sekaligus memonitor dan melakukan proses analisa dan audit terhadap asset yang dimiliki Jaringan UIN Sunan Kalijaga Yogyakarta secara rutin dan sistematis. namun tingkat kelayakan keamanan informasi masih di level I+ sampai dengan II+ Sehingga keamanan informasi pada jaringan tidak layak dan butuh perbaikan.

\section{DAFTAR PUSTAKA}

AKHIRINA, T. Y., ARIF, S. M. AND AND RAHMATIKA (2016) 'Evaluasi Keamanan Teknologi Informasi pada PT INDOTAMA PARTNER LOGISTICS Menggunakan Indeks Keamanan Informasi (KAMI)', Jurnal Nasional Teknologi dan Sistem Informasi, 2(2), pp. 53-62. doi:https://doi.org/10.25077/TEKNOSI.v2i2.201 6.53-62.

ANGGA JUANSYAH, BAGUS PRATAMA, I. D. (2018) 'Analisis dan implementasi open source security information managament (ossim) pada keamanan jaringan komputer pt. satria antaran prima palembang'. Available at: http://library.palcomtech.com/pdf/5621.pdf.

BASYARAHIL, F. A., ASTUTI, H. M. AND HIDAYANTO, B. C. (2017) 'Evaluasi Manajemen Keamanan Informasi Menggunakan Indeks Keamanan Informasi (KAMI) Berdasarkan ISO/IEC 27001:2013 Pada Direktorat Pengembangan Teknologi Dan Sistem Informasi (DPTSI) ITS Surabaya', Jurnal Teknik ITS, 6(1), p. 227. doi: 10.1016/j.juro.2016.01.039.

HADIANSYAH CHANDRA AND ISKANDAR, I. (2017) 'Pembangunan Server Security Information Management Untuk Monitoring Keamanan Di Server Diskominfo Provinsi Jawa Barat', pp. 1-8. Available at: https://repository.unikom.ac.id/53479/.

HIDAYAT, R., SUYANTO, M. AND SUNYOTO, A. (2018) 'Indeks Penilaian Keamanan Informasi Untuk Mengukur Kematangan Manajemen Keamanan Layanan TI', Pengembangan Aplikasi Untuk Mendeteksi Pergerakan Sendi Pada Pasien Pasca Stroke Menggunakan Sensor Accelerometer Di Smartphone Android, 3(1), pp. 1-7.Available at: http://ejournal.janabadra.ac.id/index.php/informasiintera ktif/article/view/671.

ISO/IEC (2018) 'INTERNATIONAL STANDARD ISO / IEC Information technology - Security techniques - Information security management systems - Overview and', 2018, p. 38. doi: 10.1177/0011128708322943.

LENAWATI, M., WINARNO, W. W. AND AMBOROWATI, A. (2017) 'Tata Kelola Keamanan Informasi pada PDAM Menggunakan
ISO/IEC 27001:2013 Dan COBIT 5', Sentra Penelitian Engineering dan Edukasi, 9(1), pp. 4449. doi: http://dx.doi.org/10.3112/speed.v9i1.1452.

MENKOMINFO (2019) 'Peraturan Menteri Komunikasi Dan Informatika Republik Indonesia Nomor 8 Tahun 2019', 8(8), pp. 1-48. doi: 10.1017/CBO9781107415324.004.

PRATAMA, E. R., SUPRAPTO AND PERDANAKUSUMA, A. R. (2018) 'Evaluasi Tata Kelola Sistem Keamanan Teknologi Informasi Menggunakan Indeks KAMI dan ISO 27001: Studi Kasus KOMINFO Provinsi Jawa Timur', Jurnal Pengembangan Teknologi Informasi dan Ilmu Komputer, 2(11), pp. 59115920. Available at: http://jptiik.ub.ac.id/index.php/j-ptiik/article/view/3465.

PUTRA, M. Y. AND TJAHJADI, D. (2018) 'Evaluasi Keamanan Informasi Pada Perguruan Tinggi Bina Insani Berdasarkan Indeks Keamanan Informasi SNI ISO/IEC 27001', PIKSEL: Penelitian Ilmu Komputer Sistem Embedded and Logic, 6(1), pp. 95-104. doi: https://doi.org/10.33558/piksel.v6i1.1404.

SUGIANTORO, B. (2017) 'Pengembangan Deteksi Penyusupan Menggunakan Multiagent', Telematika, 14(2), pp. 83-88. doi: https://doi.org/10.31315/telematika.v14i2.2095.

SUTARA, B. (2018) 'Pengukuran Keamanan Informasi PDAM Titra Medal Menggunakan Indeks KAMI Untuk Analisis Tingkat Kematangan Keamanan Informasi', 17(2), pp. 34-41. doi: https://doi.org/10.36054/jictikmi.v17i2.32. 